
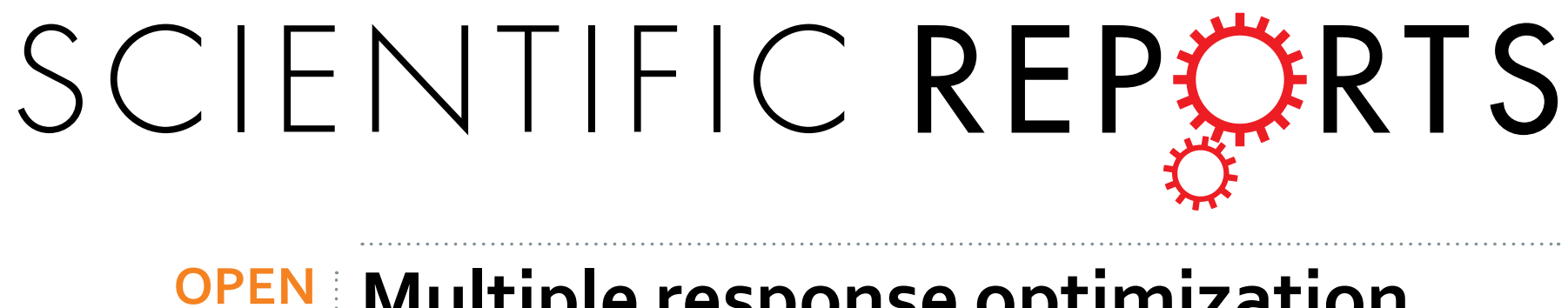

\title{
Multiple response optimization of the coagulation process for upgrading the quality of effluent \\ from municipal wastewater
}

Received: 12 January 2016

Accepted: 26 April 2016

Published: 18 May 2016

\section{treatment plant}

\author{
Na Li, Yi Hu, Yong-Ze Lu, Raymond J. Zeng \& Guo-Ping Sheng
}

To meet the high quality standard of receiving water, the coagulation process using polyferric chloride (PFC) was used to further improve the water quality of effluent from wastewater treatment plants. Uniform design (UD) coupled with response surface methodology (RSM) was adopted to assess the effects of the main influence factors: coagulant dosage, $\mathrm{pH}$ and basicity, on the removal of total organic carbon (TOC), $\mathrm{NH}_{4}{ }^{+}-\mathrm{N}$ and $\mathrm{PO}_{4}{ }^{3-}-\mathrm{P}$. A desirability function approach was used to effectively optimize the coagulation process for the comprehensive removal of TOC, $\mathrm{NH}_{4}{ }^{+}-\mathrm{N}$ and $\mathrm{PO}_{4}{ }^{3-}-\mathrm{P}$ to upgrade the effluent quality in practical application. The optimized operating conditions were: dosage $28 \mathrm{mg} / \mathrm{L}$, $\mathrm{pH} 8.5$ and basicity 0.001 . The corresponding removal efficiencies for $\mathrm{TOC}, \mathrm{NH}_{4}{ }^{+}-\mathrm{N}$ and $\mathrm{PO}_{4}{ }^{3-}-\mathrm{P}$ were $77.2 \%, 94.6 \%$ and $20.8 \%$, respectively. More importantly, the effluent quality could upgrade to surface water Class $\mathrm{V}$ of China through coagulation under optimal region. In addition, grey relational analysis (GRA) prioritized these three factors as: $\mathrm{pH}>$ basicity $>$ dosage (for TOC), basicity $>$ dosage $>\mathrm{pH}$ (for $\mathrm{NH}_{4}{ }^{+}-\mathrm{N}$ ), $\mathrm{pH}>$ dosage $>$ basicity (for $\mathrm{PO}_{4}{ }^{3-}-\mathrm{P}$ ), which would help identify the most important factor to control the treatment efficiency of various effluent quality indexes by PFC coagulation.

Biological treatment is the main process for municipal wastewater treatment. The disposal of the effluent carrying organic matters and nutrients (nitrogen and phosphorus) to the natural water bodies, will deteriorate their water quality ${ }^{1}$. Eutrophication and other adverse effects have been identified as growing problems in estuaries and coastal areas, and the presence of nutrients especially nitrogen (in the form of nitrate, nitrite, ammonia/ ammonium) and phosphorus in wastewater leads to eutrophication ${ }^{2}$. With the intent to protect receiving water, regulations are becoming stringent concerning organic carbon and nutrient levels for the effluent of wastewater treatment plants (WWTPs). A clear example in China is the stringent water quality criteria for COD and nutrients (GB 18918-2002) established by China Environmental Protection Agency in 2002 $2^{3}$ However, it is still difficult to meet the requirements of urban water environment quality, thus upgrading the quality of urban sewage treatment plant effluent is significant. So an efficient and economical tertiary treatment must be used to upgrade the quality of secondary effluent to surface water class V or class IV standard of China (GB3838-2002, shown in Table S1) to reduce the content of nutrients in receiving water.

Coagulation is a simple and efficient method for water and wastewater treatment, and has been widely used for drinking water, and wastewater treatment ${ }^{4,5}$. Inorganic salts of iron and aluminum are predominantly used in such water as coagulants. Recently, more researchers have focused on polyferric chloride (PFC) ${ }^{6,7}$, one novel coagulant containing a series of high positively preformed $\mathrm{Fe}(\mathrm{III})$ hydrolysis species. Compared with traditional $\mathrm{Fe}$-based inorganic coagulants, PFC has both strong charge neutralization and bridging abilities, which is more effective in many cases for water treatment ${ }^{8,9}$. The efficiency of the coagulation process is governed by the various factors, such as the type, dosage and basicity of the coagulant ${ }^{10-15}, \mathrm{pH}$ in the solution ${ }^{16-18}$, mixing speed and time $\mathrm{e}^{19,20}$ etc. $^{\text {. }}$ Thus, before application of PFC for the effluent treatment, a proper optimization of these factors is needed to

CAS Key Laboratory for Urban Pollutant Conversion, Department of Chemistry, University of Science and Technology of China, Hefei 230026, China. Correspondence and requests for materials should be addressed to G.-P.S. (email: gpsheng@ustc.edu.cn) 


\begin{tabular}{|c|c|c|c|c|c|c|c|c|c|c|}
\hline \multirow[b]{3}{*}{ Run } & \multicolumn{6}{|c|}{ Factors } & \multicolumn{4}{|c|}{ Responses } \\
\hline & \multicolumn{3}{|c|}{ Code } & \multicolumn{3}{|c|}{ Level } & \multirow{2}{*}{$\begin{array}{c}\text { Residual } \\
\text { TOC }(\mathrm{mg} / \mathrm{L})\end{array}$} & \multirow{2}{*}{\begin{tabular}{|c|} 
Residual \\
$\mathrm{NH}_{4}{ }^{+}-\mathrm{N}(\mathrm{mg} / \mathrm{L})$
\end{tabular}} & \multirow{2}{*}{$\frac{\text { Residual }}{\mathrm{PO}_{4}{ }^{3-}-\mathrm{P}(\mathrm{mg} / \mathrm{L})}$} & \multirow[b]{2}{*}{ D Value } \\
\hline & $\mathrm{X}_{1}$ & $\mathrm{X}_{2}$ & $\mathrm{X}_{3}$ & $\mathrm{X}_{1}(\mathrm{mg} / \mathrm{L})$ & $\mathrm{X}_{2}$ & $\mathrm{X}_{3}$ & & & & \\
\hline 1 & 1 & 6 & 5 & 2 & 6.5 & 1 & 8.71 & 1.80 & 0.23 & 0.31 \\
\hline 2 & 2 & 1 & 5 & 4 & 4 & 1 & 7.15 & 1.88 & 0.18 & 0.37 \\
\hline 3 & 3 & 6 & 4 & 6 & 6.5 & 0.75 & 7.93 & 1.84 & 0.14 & 0.38 \\
\hline 4 & 4 & 1 & 4 & 8 & 4 & 0.75 & 6.55 & 1.93 & 0.11 & 0.37 \\
\hline 5 & 5 & 7 & 3 & 10 & 7 & 0.5 & 7.10 & 1.80 & 0.10 & 0.49 \\
\hline 6 & 6 & 2 & 3 & 12 & 4.5 & 0.5 & 6.19 & 1.93 & 0.08 & 0.40 \\
\hline 7 & 7 & 7 & 2 & 14 & 7 & 0.25 & 6.91 & 1.68 & 0.05 & 0.60 \\
\hline 8 & 8 & 2 & 2 & 16 & 4.5 & 0.25 & 6.18 & 1.93 & 0.13 & 0.37 \\
\hline 9 & 9 & 8 & 1 & 18 & 7.5 & 0 & 6.57 & 1.67 & 0.05 & 0.63 \\
\hline 10 & 10 & 3 & 1 & 20 & 5 & 0 & 6.31 & 1.93 & 0.06 & 0.40 \\
\hline 11 & 11 & 8 & 5 & 22 & 7.5 & 1 & 5.97 & 1.68 & 0.04 & 0.66 \\
\hline 12 & 12 & 3 & 5 & 24 & 5 & 1 & 4.49 & 1.70 & 0.04 & 0.72 \\
\hline 13 & 13 & 9 & 4 & 26 & 8 & 0.75 & 5.78 & 1.65 & 0.03 & 0.70 \\
\hline 14 & 14 & 4 & 4 & 28 & 5.5 & 0.75 & 4.77 & 1.81 & 0.04 & 0.62 \\
\hline 15 & 15 & 9 & 3 & 30 & 8 & 0.5 & 5.44 & 1.64 & 0.03 & 0.73 \\
\hline 16 & 16 & 4 & 3 & 32 & 5.5 & 0.5 & 4.61 & 1.93 & 0.05 & 0.46 \\
\hline 17 & 17 & 10 & 2 & 34 & 8.5 & 0.25 & 5.74 & 1.72 & 0.03 & 0.65 \\
\hline 18 & 18 & 5 & 2 & 36 & 6 & 0.25 & 5.38 & 1.91 & 0.03 & 0.47 \\
\hline 19 & 19 & 10 & 1 & 38 & 8.5 & 0 & 6.00 & 1.61 & 0.02 & 0.72 \\
\hline 20 & 20 & 5 & 1 & 40 & 6 & 0 & 5.82 & 1.84 & 0.02 & 0.55 \\
\hline
\end{tabular}

Table 1. UD experimental design and the response results for coagulation processes using PFC. Note: $\mathrm{X}_{1}$, $\mathrm{X}_{2}$, and $\mathrm{X}_{3}$ represents to coagulant dosage, $\mathrm{pH}$ and basicity, respectively.

increase the treatment efficiency. In this regard, the conventional method named one-variable-at-a-time may be used to obtain the optimal conditions, but it fails to resolve the relationship between multi-variables due to the complex influences of these factors.

Response surface methodology (RSM) is an effective and efficient mathematical statistics method to build models, evaluate the effects of multiple variables and determine the optimal conditions to give desirable responses, which overcomes the limitation of the conventional method successfully ${ }^{21-24}$. In general, for the experimental design methods used in RSM, such as central composite design, if the numbers of experimental factors are increased, the numbers of coefficient of the quadratic model equations and trials are increased exponentially. In order to overcome this disadvantage, uniform design (UD) was proposed by Fang (1978). The numbers of the experimental trails using UD only are determined by the level of the factors, not by the number of the factors. Compared to the traditional experimental design method, UD is able to select experimental points uniformly in the experimental region, in which the selection of representative points in experimental domain depends on "uniformly dispersed", regardless of the "neat comparable". It provides no strong assumptions on the model and can be used even though the basic model between the response and the factor is unknown or partially unknown, and it can accommodate the number of levels for each factor in the experimental design ${ }^{25}$. Thus, UD coupled with RSM will contribute to accomplish the optimization of a complex multi-factors process with the fewest multi-levels experimental trials.

The objective of this study was to develop a multi-responses optimization method by an integrated UD-RSM experimental design for the coagulation process to improve the effluent quality from a WWTP. For this purpose, the coagulant PFC was used and the coagulation parameters in terms of coagulant dosage, $\mathrm{pH}$ and basicity were optimized via an integrated UD-RSM experimental design and a multi-responses optimization approach. The quality of effluent after the optimization of the coagulation process was evaluated in terms of the level of surface water class $\mathrm{V}$ standard of China. It is anticipated that the novel optimization strategy used in this study may provide a useful approach for other complicated systems in the environmental field.

\section{Results and Discussion}

Optimization for TOC removal. TOC removal is an important indicator for the treatment efficiency of the coagulation process. As listed in Table 1, the different coagulation conditions had distinct difference in the residual TOC concentration of the effluent. The following equation was obtained by modeling the experimental results with the nonlinear regression method:

$$
\begin{aligned}
Y= & 52.736-3.240 * X_{1}-1.228 * X_{2}-53.895 * X_{3}+0.046 * X_{1}^{2} \\
& +0.083 * X_{1} * X_{2} \\
& +1.416 * X_{1} * X_{3}-0.083 * X_{2}^{2}+1.581 * X_{2} * X_{3}+13.460 * X_{3}^{2} \\
R^{2}= & 0.87
\end{aligned}
$$


a
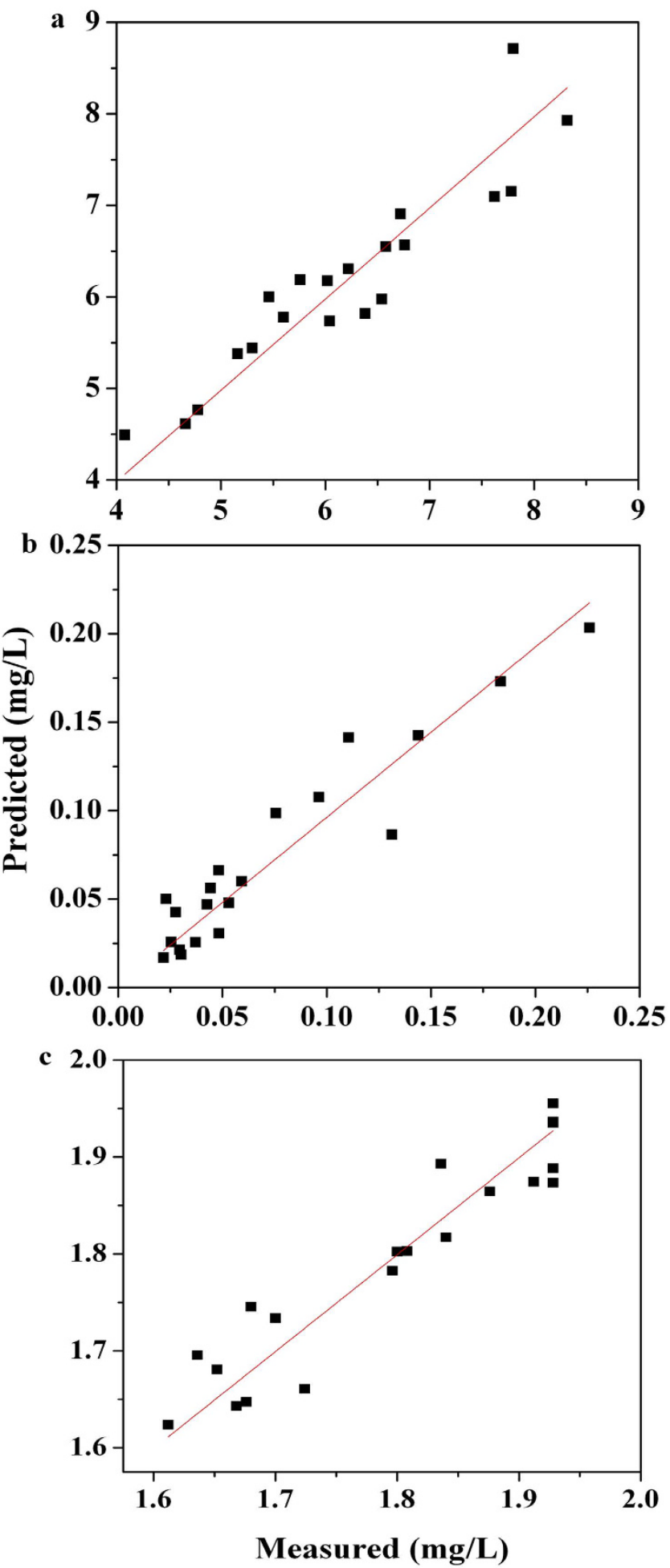

Figure 1. Relationship between the predicted and measured (a) residual TOC; (b) residual $\mathrm{PO}_{4}{ }^{3-}-\mathrm{P}$; and (c) residual $\mathrm{NH}_{4}{ }^{+}-\mathrm{N}$.

Statistical testing of the model was executed with the Fisher's statistical test for analysis of variance (ANOVA). The quadratic regression indicates that the model was significant, because the value of F-statistic (the ratio of mean square ascribed to regression to the mean square to the real error) of 14.644 was much greater than $\mathrm{F}_{0.05,1,15}$ (4.543). The high value of coefficient of determination $\left(\mathrm{R}^{2}=0.87\right)$ and the low P-values $(0.05)$ verified the sufficiency of the model. The plots of the predicted TOC residual concentration versus the measured ones are shown in Fig. 1a. Most points distributed near to the straight line, indicating that the regression model was able to predict these residual TOC concentrations. The optimized conditions to obtain the lowest TOC residue concentration 
were obtained by setting the partial differential of the response (Eq. 1) to zero as follows: coagulant dosage of $24 \mathrm{mg} / \mathrm{L}$, $\mathrm{pH}$ of 7.5 and basicity of 0.30 , where the minimum concentration of TOC was calculated to be $1.17 \mathrm{mg}$ $\mathrm{C} / \mathrm{L}$, which was equivalent to $4.7 \mathrm{mg} \mathrm{COD} / \mathrm{L}$ (according to the empirical value obtained through analyzing the relationship between TOC and COD in sewage treatment plants ${ }^{26}$ ). The removal efficiency was $85.9 \%$.

The effects of coagulant dosage, $\mathrm{pH}$ and basicity on the TOC concentration as the response are shown in the 3-dimentional response surface graph (Fig. 2). The distinct peak in the response surfaces indicates that the optimal conditions were exactly in the experimental region. In other words, there were significant interactive effects on TOC removal between the three factors.

Optimization for $\mathrm{PO}_{4}{ }^{3-}-\mathrm{P}$ removal. $\mathrm{PO}_{4}{ }^{3-}-\mathrm{P}$ content is regarded as one of the important factors controlling water eutrophication ${ }^{27}$. It is essential to remove $\mathrm{PO}_{4}{ }^{3-}-\mathrm{P}$ from the effluent before it is discharged to receiving water. The effects of various coagulation operation parameters on the removal of $\mathrm{PO}_{4}{ }^{3-}-\mathrm{P}$ using $\mathrm{PFC}$ could be described by the following equation, which was obtained by modeling the results in coagulation experiments with the nonlinear regression method:

$$
\begin{aligned}
Y= & -0.147+0.006 * X_{1}+0.290 * X_{2}+0.189 * X_{3}-0.0004 * X_{1}^{2} \\
& +0.003 * X_{1} * X_{2} \\
& -0.001 * X_{1} * X_{3}-0.026 * X_{2}^{2}-0.029 * X_{2} * X_{3}-0.054 * X_{3}^{2} \\
R^{2}= & 0.90
\end{aligned}
$$

The results of $\mathrm{F}=18.175>\mathrm{F}_{0.05,1,15}=4.543$ and $\mathrm{R}^{2}=0.90$ for the $\mathrm{PO}_{4}{ }^{3-}$-P removal efficiency illustrated that the second-order polynomial model fitted the experimental results well. Figure $1 \mathrm{~b}$ shows that the measured versus predicted plot values were distributed evenly near to the straight line. From Eq. 2, the optimized conditions for the minimum residual $\mathrm{PO}_{4}{ }^{3-}-\mathrm{P}$ concentration were calculated to be: coagulant dosage of $32 \mathrm{mg} / \mathrm{L}, \mathrm{pH}$ of 7.0 and basicity of 0.25 . Under these conditions the residual $\mathrm{PO}_{4}{ }^{3-}-\mathrm{P}$ concentration was calculated to be $0.01 \mathrm{mg} / \mathrm{L}$, and the removal efficiency was $99.9 \%$.

When the residual concentration of $\mathrm{PO}_{4}{ }^{3-}-\mathrm{P}$ was chosen as the response, the response surfaces of the quadratic model that one variable kept at the optimal value and the other two varied within the experimental ranges, respectively, are illustrated in Fig. 3. The distinct peak in the response surfaces indicates that the optimal conditions were exactly located inside the design boundary. The elliptical contour plots imply that there were significant interactive effects on $\mathrm{PO}_{4}{ }^{3-}$-P removal between the three factors.

Optimization for $\mathrm{NH}_{4}{ }^{+}-\mathrm{N}$ removal. The regression model to describe the $\mathrm{NH}_{4}{ }^{+}-\mathrm{N}$ removal efficiency of the coagulation experiments was obtained using the backward regression method:

$$
\begin{aligned}
Y= & -0.615+0.017 * X_{1}+0.104 * X_{2}+0.336 * X_{3}-0.0004 * X_{1}^{2} \\
& +0.067 * X_{1} * X_{2} \\
& -0.006 * X_{1} * X_{3}-0.0041 * X_{2}^{2}-0.0405_{*} X_{2} * X_{3}+0.081 * X_{3}^{2} \\
R^{2}= & 0.85
\end{aligned}
$$

The quadratic regression indicates a high significance of the model, because the value of F-statistic of 6.30 was much greater than $\mathrm{F}_{0.05,1,14}(4.60)$. The high value of the correlation coefficient $\left(\mathrm{R}^{2}=0.85\right)$ suggests a good agreement between the measured and predicted values of the residual $\mathrm{NH}_{4}{ }^{+}-\mathrm{N}$ concentration (Fig. 1c). Then, the optimal conditions for maximum $\mathrm{NH}_{4}{ }^{+}-\mathrm{N}$ removal were calculated to be: coagulant dosage of $27 \mathrm{mg} / \mathrm{L}, \mathrm{pH}$ of 8.5 and basicity of 0.001 . In this case, the minimum concentration of residual $\mathrm{NH}_{4}{ }^{+}-\mathrm{N}$ was calculated to be $1.52 \mathrm{mg} / \mathrm{L}$ and the removal efficiency was only $20.6 \%$.

The response surfaces of the quadratic model with the concentration of residual $\mathrm{NH}_{4}{ }^{+}-\mathrm{N}$ as the response are shown in Fig. 4. The contour plots imply that there were significant interactive effects on $\mathrm{NH}_{4}^{+}-\mathrm{N}$ removal between dosage and $\mathrm{pH}$, dosage and basicity, as well as $\mathrm{pH}$ and basicity. This was evidenced by the obvious peak in the response surface, in which the optimal conditions were exactly located in the experimental range.

Removal mechanisms for $\mathrm{TOC}, \mathrm{PO}_{4}{ }^{3-}-\mathrm{P}$ and $\mathrm{NH}_{4}{ }^{+}-\mathrm{N}$ by PFC. The residual organics in the effluent from the biological WWTPs include humic substances, proteins, microbial products and other inert matters, most of them are biopolymers and in the form of colloids ${ }^{28,29}$. The removal mechanisms of these organics through coagulation include a combination of charge neutralization, entrapment, adsorption and complexation with the iron based coagulant into insoluble particulate aggregates ${ }^{4}$. PFC was pre-hydrolyzed in the preparation process, and when it was dosed to the solution, it could slow down the rate of hydrolysis of PFC species through dilution. So PFC species might have sufficient time to react with the organic matters. More polymeric species with higher positive charge density were formed with the increase of basicity, which benefited TOC removal by adsorption and charge neutralization. Under these conditions, the coagulant PFC exhibited good charge neutralization, bridging and sweep-floc abilities, which contributed the high TOC removal efficiency.

The coagulation of $\mathrm{PO}_{4}{ }^{3-}-\mathrm{P}$ with $\mathrm{Fe}(\mathrm{III})$ salts includes two major mechanisms: formation of Fe-hydroxo-phosphate complexes, $\mathrm{Fe}(\mathrm{OH})_{3-\mathrm{x}}\left(\mathrm{PO}_{4}\right)_{\mathrm{x}}$, which either absorbs onto positively charged $\mathrm{Fe}$ (III) hydrolyzed species or precipitates with $\mathrm{Fe}(\mathrm{III})$ hydrolyzed products as the centers; and adsorption of $\mathrm{PO}_{4}{ }^{3-}-\mathrm{P}$ ions with polymeric species ${ }^{9,30}$. The $\mathrm{pH}$ plays an important role in the PFC coagulation process, and the PFC flocs formed at a neutral condition would give the largest floc size $\mathrm{e}^{7}$. In addition, basicity is one of the important factors that affects the nature of Fe(III) species, thereby affecting coagulation performance. Therefore, under the optimized 

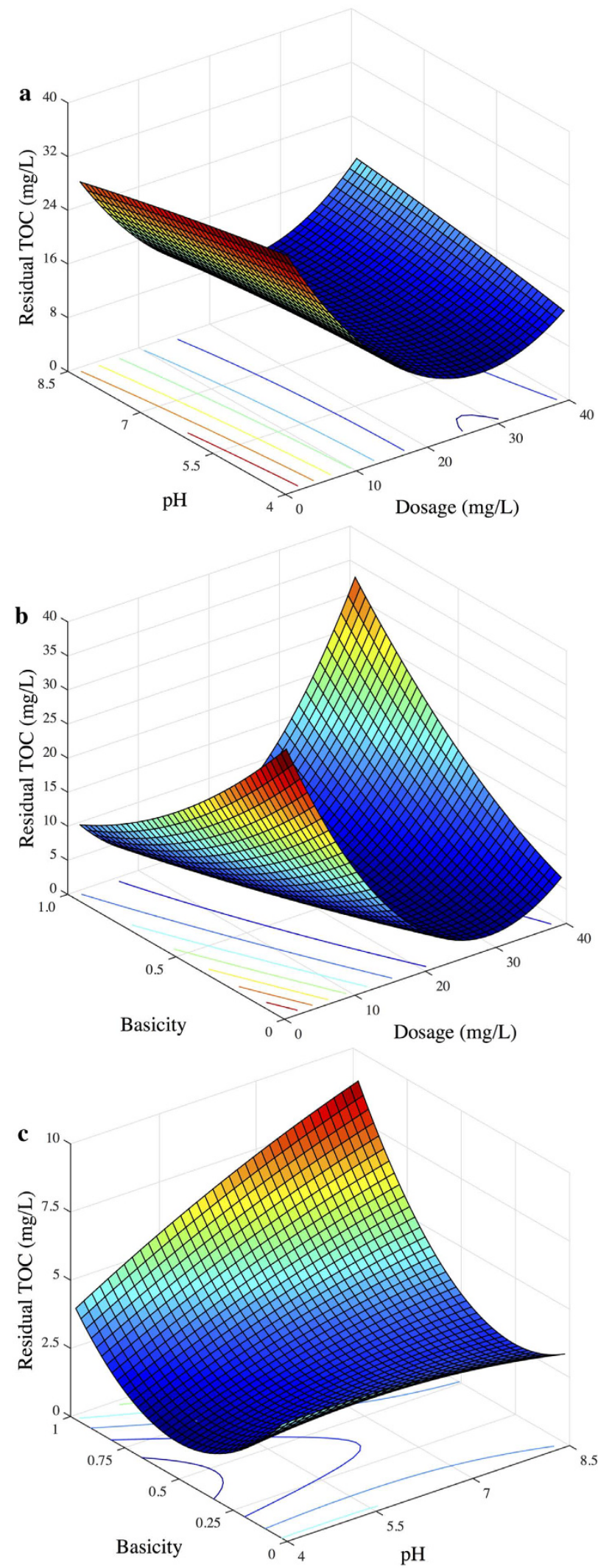

Figure 2. $3 \mathrm{D}$ surface graphs and contour plots of the residual TOC concentration: effect of variables $(\mathbf{a}) \mathrm{X}_{1}-\mathrm{X}_{2}$; (b) $\mathrm{X}_{1}-\mathrm{X}_{3}$; and $\mathrm{X}_{2}-\mathrm{X}_{3}$. 

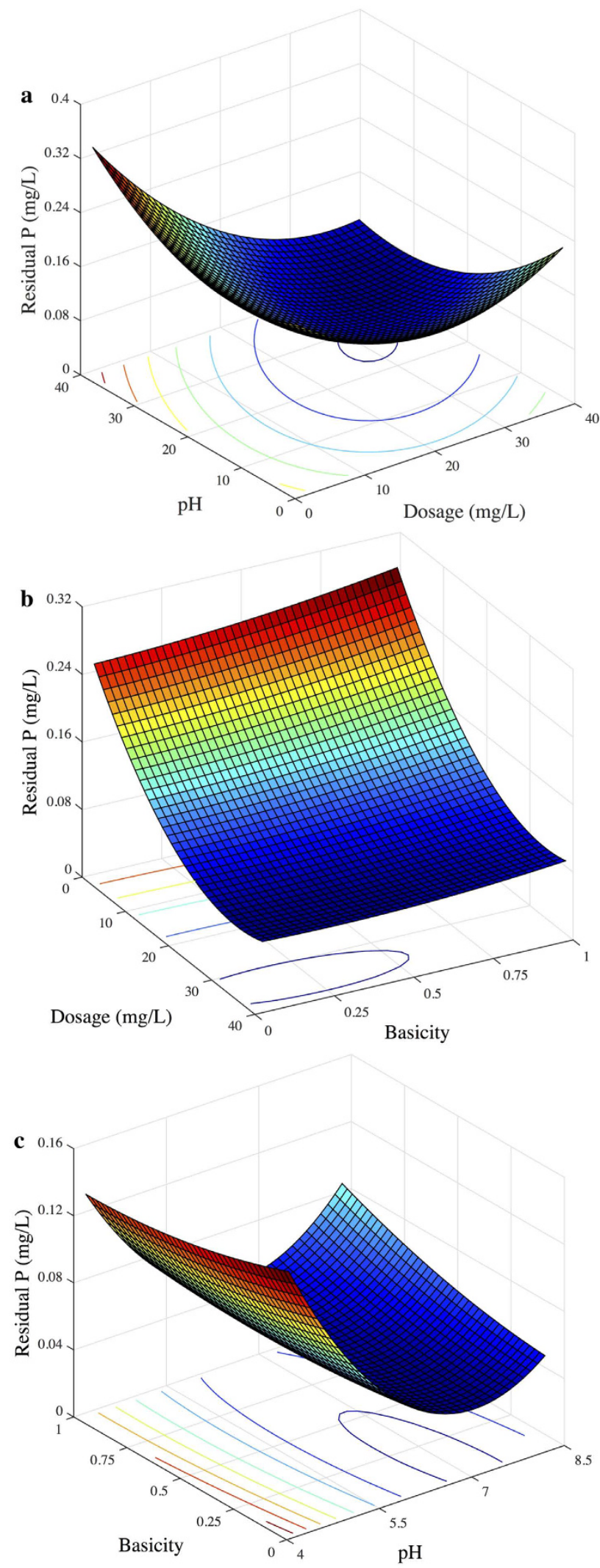

Figure 3. $3 \mathrm{D}$ surface graphs and contour plots of the residual $\mathrm{PO}_{4}{ }^{3-}-\mathrm{P}$ concentration: effect of variables (a) $\mathrm{X}_{1}-\mathrm{X}_{2}$; (b) $\mathrm{X}_{1}-\mathrm{X}_{3}$; and $\mathrm{X}_{2}-\mathrm{X}_{3}$. 

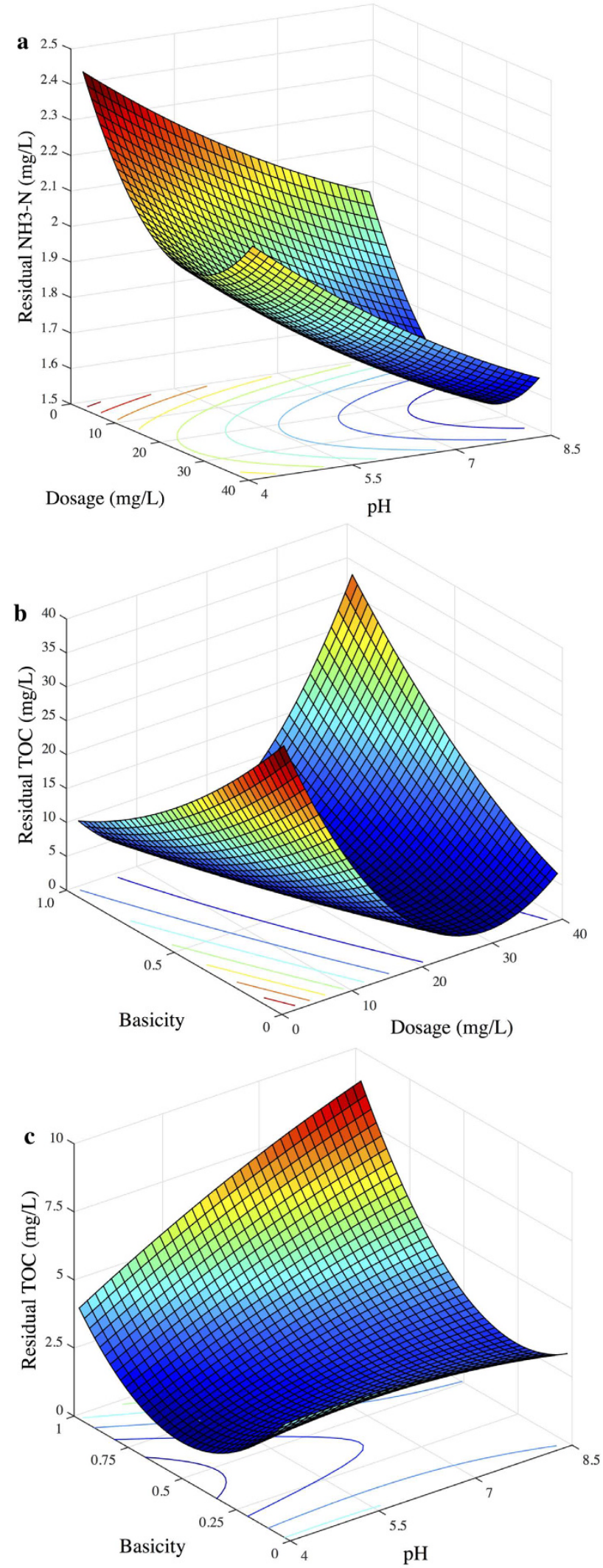

Figure 4. 3D surface graphs and contour plots of the residual $\mathrm{NH}_{4}{ }^{+}-\mathrm{N}$ concentration: effect of variables (a) $\mathrm{X}_{1}-\mathrm{X}_{2}$; (b) $\mathrm{X}_{1}-\mathrm{X}_{3}$; and $\mathrm{X}_{2}-\mathrm{X}_{3}$. 


\begin{tabular}{|l|l|l|c|c|}
\hline Run & Condition & Response values & $\begin{array}{c}\text { Measured } \\
\text { value }(\mathbf{m g} / \mathrm{L})\end{array}$ & $\begin{array}{c}\text { Calculated } \\
\text { value }(\mathbf{m g} / \mathrm{L})\end{array}$ \\
\hline 21 & $\begin{array}{l}\text { PFC dosage: } \\
24.0 \mathrm{mg} / \mathrm{L} \mathrm{pH}: 7.5 \\
\text { Basicity: 0.30 }\end{array}$ & Residual TOC concentration & $1.85 \pm 0.15$ & 1.17 \\
\hline 22 & $\begin{array}{l}\text { PFC dosage: } \\
32.0 \mathrm{mg} / \mathrm{L} \mathrm{pH:} 7.0 \\
\text { Basicity: 0.25 }\end{array}$ & Residual $\mathrm{PO}_{4}{ }^{3-}-\mathrm{P}$ concentration & $0.05 \pm 0.02$ & 0.01 \\
\hline 23 & $\begin{array}{l}\text { PFC dosage: } \\
27 \text { mg/L pH: } 8.5 \\
\text { Basicity: } 0\end{array}$ & Residual $\mathrm{NH}_{4}{ }^{+}-\mathrm{N}$ concentration & $1.52 \pm 0.05$ & 1.53 \\
\hline
\end{tabular}

Table 2. Measured and calculated values for the confirmation experiments.

conditions, the coagulant PFC exhibited good absorption and sweep-floc abilities, and had a good performance for $\mathrm{PO}_{4}{ }^{3-}$-P removal.

Because the coagulation process does not remove $\mathrm{NH}_{4}{ }^{+}-\mathrm{N}$ directly, the removal efficiency of $\mathrm{NH}_{4}{ }^{+}-\mathrm{N}$ was not very high. After PFC was dosed to the solution, the pre-hydrolyzed Fe species would enmesh and co-precipitate with the colloidal particles in wastewater, and then settle together. Partial of $\mathrm{NH}_{4}^{+}-\mathrm{N}$ could bind to the surface of the negatively charged colloidal particles by electrostatic attraction ${ }^{31}$. As a result, partial $\mathrm{NH}_{4}{ }^{+}-\mathrm{N}$ could be removed from the wastewater together with the colloid particles.

Different removal mechanisms lead to the different optimal removal conditions, which are consistent with the above results. Furthermore, to confirm the validity of the statistical experimental strategies, additional confirmation experiments based on the optimized coagulation conditions above were conducted. The chosen conditions and results are listed in Table 2. The measured concentrations of residual TOC, $\mathrm{PO}_{4}{ }^{3-}-\mathrm{P}_{\text {and }} \mathrm{NH}_{4}{ }^{+}-\mathrm{N}$ were close to the calculated values by their respective regression models. This result demonstrated that UD-RSM approach was useful for optimizing the coagulation process parameters, in terms of minimizing the effluent concentrations of TOC, $\mathrm{PO}_{4}{ }^{3-}-\mathrm{P}$ and $\mathrm{NH}_{4}{ }^{+}-\mathrm{N}$.

Optimization for multiple responses of TOC, $\mathrm{NH}_{4}{ }^{+}-\mathrm{N}$ and $\mathrm{PO}_{4}{ }^{3-}-\mathrm{P}$ removal. The optimization for individual removal of TOC, $\mathrm{PO}_{4}{ }^{3-}-\mathrm{P}$ or $\mathrm{NH}_{4}{ }^{+}-\mathrm{N}$ achieved under the different optimal conditions is a big concern in real wastewater treatment. Thus, it is necessary to consider the comprehensive removal of TOC, $\mathrm{PO}_{4}{ }^{3-}-\mathrm{P}$, and $\mathrm{NH}_{4}{ }^{+}-\mathrm{N}$ in practical application. In this work, a desirability function approach ${ }^{32,33}$ was used to optimize multiple responses in order to obtain a good quality of the effluent to match high water quality of receiving water. The completely desirable values of the response residual concentrations of TOC, $\mathrm{PO}_{4}{ }^{3-}-\mathrm{P}$ and $\mathrm{NH}_{4}{ }^{+}-\mathrm{N}^{-}$were set at 1.19 , 0.01 and $1.52 \mathrm{mg} / \mathrm{L}$, respectively, which were the lowest residual concentrations of TOC, $\mathrm{PO}_{4}{ }^{3-}-\mathrm{P}$, and $\mathrm{NH}_{4}{ }^{+}-\mathrm{N}$ obtained under the individual optimal conditions. And the completely undesirable values of those responses were above 10 (equivalent to $40 \mathrm{mg} \mathrm{COD} / \mathrm{L}$ ), 0.4 and $2.0 \mathrm{mg} / \mathrm{L}$, respectively, which was based on surface water class $\mathrm{V}$ of China ${ }^{3}$. Then the values of desirability function $D$ obtained by calculating the geometric mean of the three individual ideal functions at various experimental conditions are listed in Table 1, and was regressed using the following equation:

$$
\begin{aligned}
D= & -1.31+0.061 * X_{1}+0.248 * X_{2}+1.141 * X_{3}-0.001 * X_{1}^{2} \\
& +0.0002 * X_{1} * X_{2} \\
& -0.017 * X_{1} * X_{3}-0.012 * X_{2}^{2}-0.11 * X_{2} * X_{3}+0.020 * X_{3}^{2} \\
R^{2}= & 0.91
\end{aligned}
$$

The optimal conditions were calculated to be: dosage of $28 \mathrm{mg} / \mathrm{L}, \mathrm{pH} 8.5$, and basicity 0.001 , respectively. The corresponding residual concentrations of TOC, $\mathrm{PO}_{4}{ }^{3-}-\mathrm{P}, \mathrm{NH}_{4}{ }^{+}-\mathrm{N}$ concentration and $\mathrm{D}$ value were $1.41 \mathrm{mg} / \mathrm{L}$, $0.03 \mathrm{mg} / \mathrm{L}$, and $1.53 \mathrm{mg} / \mathrm{L}$ and 0.90 , respectively. The overlay plot for the optimal region is presented in Fig. 5 . The shaded portion gave the permissible values of the variables by defining the desired limits of the concentrations of TOC, $\mathrm{PO}_{4}{ }^{3-}-\mathrm{P}$ and $\mathrm{NH}_{4}{ }^{+}-\mathrm{N}$ as $10 \mathrm{mg} / \mathrm{L}, 0.4 \mathrm{mg} / \mathrm{L}$ and $2.0 \mathrm{mg} / \mathrm{L}$, respectively, and the treated effluent satisfied surface water Class V standard of China.

A confirmation experiment under the compromised conditions was carried out in duplicates, and the concentrations of TOC, $\mathrm{PO}_{4}{ }^{3-}-\mathrm{P}$, and $\mathrm{NH}_{4}{ }^{+}-\mathrm{N}$ in the obtained effluent were 2.49 (equivalent to $10.0 \mathrm{mg} \mathrm{COD} / \mathrm{L}$ ), 0.05 , and $1.52 \mathrm{mg} / \mathrm{L}$, respectively, and these results were in good agreement with the predicted ones, and the differences between predicted and experimental values were $0.90,0.02$, and $0.01 \mathrm{mg} / \mathrm{L}$, respectively. As shown in Table 3, the effluent index, including the concentrations of TOC, $\mathrm{PO}_{4}{ }^{3-}-\mathrm{P}$, and $\mathrm{NH}_{4}{ }^{+}-\mathrm{N}$, dropped significantly after the treatment under the optimal conditions, especially for the $\mathrm{PO}_{4}{ }^{3-}-\mathrm{P}$ concentration (with a removal efficiency of $90.9 \%$ ), which was reduced one order of magnitude compared to the value before the treatment, and the treated effluent could reach to surface water Class V standard of China.

Influential priority of the three factors. GRA method was used to evaluate the influential degrees of dosage, $\mathrm{pH}$, and basicity on the removal of TOC, $\mathrm{NH}_{4}{ }^{+}-\mathrm{N}$ and $\mathrm{PO}_{4}{ }^{3-}-\mathrm{P}$ by coagulation using $\mathrm{PFC}$. The grey relational grades $\gamma$ of these factors for the treatment performance were calculated to be: 

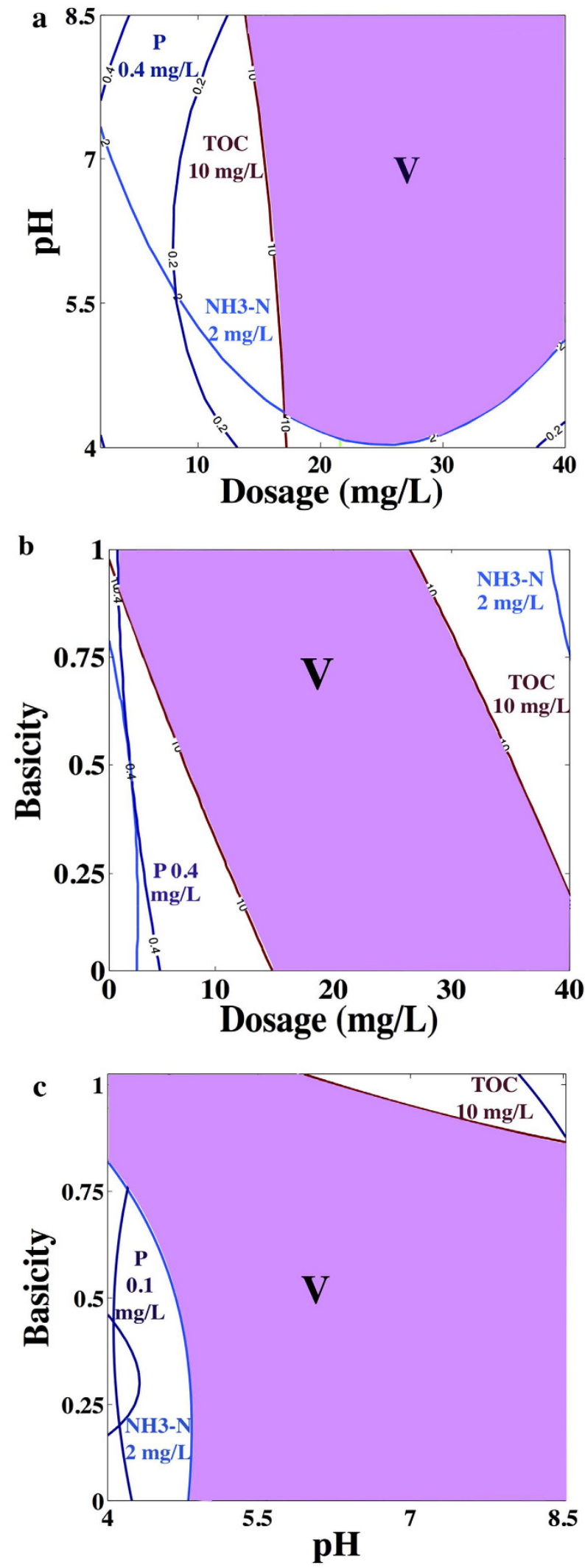

Figure 5. Overlay plot for the optimal region (surface water class V standard of China). 


\begin{tabular}{|l|c|c|c|}
\hline Parameters & \multicolumn{1}{|c|}{$\begin{array}{c}\text { Before } \\
\text { treatment }\end{array}$} & $\begin{array}{c}\text { After } \\
\text { treatment } \\
\text { (optimal) }\end{array}$ & $\begin{array}{c}\text { Treatment } \\
\text { efficiency (\%) }\end{array}$ \\
\hline $\mathrm{TOC}(\mathrm{mg} / \mathrm{L})$ & $8.65-11.75$ & $2.49 \pm 0.18$ & $73.2 \pm 0.2$ \\
\hline $\mathrm{PO}_{4}{ }^{3-}-\mathrm{P}(\mathrm{mg} / \mathrm{L})$ & $0.55 \pm 0.05$ & $0.05 \pm 0.01$ & $90.9 \pm 0.2$ \\
\hline $\mathrm{NH}_{4}{ }^{+}-\mathrm{N}(\mathrm{mg} / \mathrm{L})$ & $1.65-2.61$ & $1.52 \pm 0.05$ & $18.8 \pm 0.2$ \\
\hline
\end{tabular}

Table 3. Effluent quality from a local wastewater treatment plant before and after coagulation treatment under optimal conditions (Dosage of $28 \mathrm{mg} / \mathrm{L}, \mathrm{pH}$ of 8.5 , basicity of 0.001 ).

$$
\begin{gathered}
\gamma(\text { TOC })=\left(X_{1} X_{2} X_{3}\right)=\left(\begin{array}{lll}
0.7623 & 0.7665 & 0.7663
\end{array}\right) \\
\gamma\left(N H_{4}^{+}-N\right)=\left(X_{1} X_{2} X_{3}\right)=\left(\begin{array}{lll}
0.7067 & 0.7030 & 0.7159
\end{array}\right) \\
\gamma\left(P O_{4}^{3-}-P\right)=\left(X_{1} X_{2} X_{3}\right)=\left(\begin{array}{lll}
0.6075 & 0.6185 & 0.5929
\end{array}\right)
\end{gathered}
$$

Results showed that the influential priorities on the removal of TOC, $\mathrm{NH}_{4}{ }^{+}-\mathrm{N}$ and $\mathrm{PO}_{4}{ }^{3-}-\mathrm{P}$ in the effluent after coagulation were quite different. The $\mathrm{pH}$ showed the most significant effect on TOC removal, followed by basicity. Dosage exhibited a less-significant effect. For $\mathrm{NH}_{4}{ }^{+}-\mathrm{N}$, the influential priorities were in the order of: basicity $>$ dosage $>\mathrm{pH}$. In contrast, the influential priorities of these factors on $\mathrm{PO}_{4}{ }^{3-}-\mathrm{P}$ removal were in the order of: $\mathrm{pH}>$ dosage $>$ basicity. The results in this work also demonstrated that $\mathrm{pH}$ was the most significant factor affecting the removal of organic matters and $\mathrm{PO}_{4}{ }^{3-}-\mathrm{P}$ from the WWTP effluent by coagulation using PFC. The $\mathrm{pH}$ determines the hydrolysis of PFC species and floc sizes, which in turn affect the coagulation mechanism. Because of the slow hydrolysis of PFC under acidic condition, the charge neutralization dominates the coagulation process of PFC. The hydrolysis tendency of PFC becomes much larger with $\mathrm{pH}$ increased, while bridging, absorption and sweep-floc play important roles in coagulation process of PFC. Furthermore, coagulants give bigger final floc sizes at neutral and alkaline conditions than acidic conditions which benefit the removal for $\mathrm{PO}_{4}{ }^{3-}$-P. This result agreed with previous studies, in which $\mathrm{pH}$ was also found to play an important role in the coagulation process using $\mathrm{PFC}^{6,7}$. In contrast, basicity, rather than $\mathrm{pH}$ and dosage that are usually considered in the coagulation process for wastewater ${ }^{34}$ or drink water ${ }^{35}$ treatment, was found to be the crucial factor influencing the removal of $\mathrm{NH}_{4}^{+}-\mathrm{N}$ in this study. Basicity determines the species of pre-hydrolyzed products in preparation process of PFC. The hydrolyzed Fe species, such as amorphous ferric hydroxide precipitates, exhibit good enmesh and co-precipitate abilities with the colloidal particles, and in turn cause the reduction of $\mathrm{NH}_{4}{ }^{+}-\mathrm{N}_{\text {bound }}$ to them.

Implications of this study. An integration of UD and RSM, with a rational statistical basis, is proved to be a valid approach for the optimization of the coagulation process for the treatment of the effluent from WWTP. The response variable was fitted by a second-order model when using the regression method to describe the relationship between the dependent output variable and the independent variables with the fewest multi-levels experimental trials. The value of $\mathrm{F}$-statistic was much greater than $\mathrm{F}_{0.05}$ indicated that the model was significant, and the high value of coefficient of determination $\left(R^{2}>0.85\right)$, a sufficient large residual degree of freedom $(17$, much higher than 5) and the low P-values (0.05) verified the sufficiency of the model, these all illustrated the second-order model was suitable and effective in this study. Under the optimized conditions, the treated effluent could reach to surface water Class V standard of China. Due to serious water pollution in China, the WWTPs need to upgrade to meet the increasing strict discharge regulation, indicating that the sewage treatment plants face the problem of upgrading and reconstruction. The coagulation process is easy to implement without big changes in structures or technological process of sewage treatment plant. This integrated optimized approach for PFC coagulation also could further improve the effluent quality to meet the surface water Class V standard of China, which may significantly reduce the pollution of the receiving water body. However, the efficiency of the coagulation process is governed by the various factors, such as the type, dosage and basicity of the coagulant, $\mathrm{pH}$ in the solution, the characteristics of wastewater, e.g. anion, cation, the type and concentration of pollutants etc. Thus, the optimized parameters for coagulation obtained in this study may not be applicable for other sewage treatment plants, but it is suitable to upgrade the quality of the effluent from sewage treatment plants through coagulation by the multi-response optimization method.

Meanwhile, this study shows that this UD approach effectively optimizes the coagulation process by taking advantage of few data sets and factors with different levels, which is very attractive for the processes where data are obtained hardly or expensively. Thus, this optimization approach can be applicable for other complex or multivariate systems in the environmental field. UD focuses on the selected experimental points distributing uniformly within the factor space for all the three key factors with different levels influencing the efficiency of this process, i.e., dosage, $\mathrm{pH}$ and basicity in this study. Thus most response information is obtained through the fewest numbers of the experiments and multilevel factors. These characteristics are the advantages of UD compared with other experimental design approaches.

However, in addition to the treatment efficiency, the cost is also a big concern in practical application. GRA is adopted to assess the influential priorities of factors, which does a favor for selecting the most important factor, ultimately achieving a balance between the treatment efficiency and the cost. For example, GRA results show that basicity and $\mathrm{pH}$ have the most and least significant effect on the residual $\mathrm{NH}_{4}^{+}-\mathrm{N}$ concentration, respectively. 


\begin{tabular}{|l|c|}
\hline Parameters & Measured \\
\hline $\mathrm{TOC}(\mathrm{mg} / \mathrm{L})$ & $8.65-11.75$ \\
\hline $\mathrm{PO}_{4}{ }^{3-}(\mathrm{mg} / \mathrm{L})$ & $0.55 \pm 0.05$ \\
\hline $\mathrm{NO}_{3}{ }^{-}(\mathrm{mg} / \mathrm{L})$ & $13.75 \pm 0.25$ \\
\hline $\mathrm{NH}_{4}{ }^{+}(\mathrm{mg} / \mathrm{L})$ & $1.65-2.61$ \\
\hline $\mathrm{pH}$ & $7.30 \pm 0.20$ \\
\hline Temperature $\left({ }^{\circ} \mathrm{C}\right)$ & 25 \\
\hline
\end{tabular}

Table 4. Characteristics of effluent from the wastewater treatment plants.

However, the $\mathrm{pH}$ is usually uncontrollable in WWTPs before the coagulation process, while the basicity of commonly used coagulant PFC is determined with the experience without optimization during practical application. The results of UD and RSM reveal that $\mathrm{NH}_{4}{ }^{+}-\mathrm{N}$ removal could be improved through adjusting the basicity of PFC. Therefore, in the practical application, the sewage of high ammonium content could be treated without $\mathrm{pH}$ adjustment, which could reduce the operation cost to improve the effluent quality. All of these indicate that the results of UD, RSM and GRA are complementary. Through the multi-responses optimization of coagulation (a simple and efficient water treatment process), the water quality of the effluent from a WWTP could be upgraded to surface water class $\mathrm{V}$ of China.

\section{Conclusions}

In present work, a coagulation process with PFC was employed to treat the effluent from a WWTP to improve the effluent quality. A multiple responses optimized method RSM coupled with UD was used to successfully optimize the process, and the individual and interactive effects of the main influential factors were evaluated. An optimal condition of coagulant dosage $28 \mathrm{mg} / \mathrm{L}, \mathrm{pH} 8.5$ and basicity 0.001 was obtained when considering the removal of TOC, $\mathrm{PO}_{4}{ }^{3-}-\mathrm{P}$ and $\mathrm{NH}_{4}{ }^{+}-\mathrm{N}$ simultaneously. More importantly, the water quality of the treated effluent after $\mathrm{PFC}$ coagulation could reach surface water class V of China under the optimal region. This indicated that the PFC coagulation process after optimization could efficiently improve the quality of the effluent from WWTPs to meet more and more strict wastewater discharge policy.

\section{Methods}

PFC preparation and coagulation experiment. PFC used in the experiments was prepared by slowly adding $\mathrm{Na}_{2} \mathrm{CO}_{3}$ powder to a certain concentration of $\mathrm{FeCl}_{3}$ solutions under the stirring conditions at room temperature. The amount of $\mathrm{Na}_{2} \mathrm{CO}_{3}$ added to $\mathrm{FeCl}_{3}$ solution was varied depending on the target basicity $\mathrm{B}$ $\left(\mathrm{B}=\left[\mathrm{OH}^{-}\right] /\left[\mathrm{Fe}^{3+}\right]\right)$ at $0,0.25,0.50,0.75$ and 1.00 . After the foam disappeared and the solution became transparent, $\mathrm{Na}_{2} \mathrm{HPO}_{4}$ was added to the solution as a stabilizer $\left(\left[\mathrm{Na}_{2} \mathrm{HPO}_{4}\right] /[\mathrm{Fe}]=0.08\right)$. The concentration of $\mathrm{Fe}$ was $7 \%$ $(\mathrm{w} / \mathrm{w})$ in the PFC solution. The dosages of PFC were calculated as $\mathrm{mg} / \mathrm{L}$ of Fe during coagulation. All reagents used were of analytical grade.

The raw effluent was sampled from the secondary sedimentation tank in a local municipal wastewater treatment plant in Hefei, China, and stored at $4^{\circ} \mathrm{C}$. Before each experiment, the temperature of all samples was controlled at the room temperature of $24 \pm 1{ }^{\circ} \mathrm{C}$. The raw effluent samples were characterized in terms of total organic carbon (TOC), $\mathrm{pH}, \mathrm{NH}_{4}{ }^{+}-\mathrm{N}, \mathrm{PO}_{4}{ }^{3-}-\mathrm{P}$ and $\mathrm{NO}_{3}{ }^{-}-\mathrm{N}$. The properties of the samples listed in Table 4 were: TOC $10.20 \pm 1.55 \mathrm{mg} / \mathrm{L}, \mathrm{PO}_{4}{ }^{3-}-\mathrm{P} 0.55 \pm 0.05 \mathrm{mg} / \mathrm{L}, \mathrm{NH}_{4}{ }^{+}-\mathrm{N} 2.15 \pm 0.50 \mathrm{mg} / \mathrm{L}, \mathrm{NO}_{3}{ }^{-}-\mathrm{N} 13.75 \pm 0.25 \mathrm{mg} / \mathrm{L}, \mathrm{pH}$ $7.3 \pm 0.2$.

A series of jar tests were carried out in 1-L breakers. After the solution $\mathrm{pH}$ was adjusted from 4 to 8.5 by adding $0.1 \mathrm{M} \mathrm{HCl}$ or $\mathrm{NaOH}$ solutions, the PFCs with different basicity were added to the solution with a dosage of $2-40 \mathrm{mg} / \mathrm{L}$. The samples were immediately stirred at $200 \mathrm{rpm}$ for $2 \mathrm{~min}$, and then stirred at a lower speed of $30 \mathrm{rpm}$ for $20 \mathrm{~min}$, followed by a settlement for $30 \mathrm{~min}$. The samples were taken from about $2 \mathrm{~cm}$ below the surface and then filtered with $0.45 \mu \mathrm{m}$ membrane to measure TOC, $\mathrm{NH}_{4}{ }^{+}-\mathrm{N}, \mathrm{PO}_{4}{ }^{3-}-\mathrm{P}$.

$\mathrm{PO}_{4}{ }^{3-}-\mathrm{P}$ and $\mathrm{NH}_{4}{ }^{+}-\mathrm{N}$ were measured by a water quality autoanalyzer (Aquakem 200 , ThermoFisher, Finland) following the standard methods (APHA, 1998), and TOC was measured via a TOC analyzer (multi N/C 2100, Analytikjena, Germany).

Experimental design with UD. $\quad \mathrm{U}_{\mathrm{n}}\left(\mathrm{q}^{\mathrm{m}}\right)$ can be used to describe UD table, wherein, $\mathrm{U}, n, q$ and $m$ represent the UD, the number of experimental trials, the number of levels and the maximum number of factors, respectively. In this study, coagulant dosage $\left(\mathrm{X}_{1}\right), \mathrm{pH}\left(\mathrm{X}_{2}\right)$, and basicity $\left(\mathrm{X}_{3}\right)$ were selected as three independent variables in the coagulation process. Twenty levels, ten levels and five levels were chosen for $\mathrm{X}_{1}, \mathrm{X}_{2}, \mathrm{X}_{3}$, respectively, to investigate the effect and interaction of the factors on coagulation. When considering the operability of all factors and ensuring the accuracy of the experiments, a mixed-level UD table with the different number of levels of each factor, $\mathrm{U}_{20}\left(20^{\star} 10^{\star} 5\right)$ with discrepancy of 0.1664 in uniformity, was chosen to carry out the experiments. The range and levels of each factor are listed in Table 1.

The responses included the removal of TOC, $\mathrm{NH}_{4}{ }^{+}-\mathrm{N}$ and $\mathrm{PO}_{4}{ }^{3-}-\mathrm{P}$, which represented the overall wastewater treatment efficiency. The response variable was fitted by a second-order model using the regression method to describe the relationship between the dependent output variable and the independent variables.

$$
\mathrm{Y}=\mathrm{b}_{0}+\sum_{\mathrm{i}=1}^{\mathrm{j}} \mathrm{b}_{\mathrm{i}} \mathrm{X}_{\mathrm{i}}+\sum_{\mathrm{i}=1}^{\mathrm{k}} \mathrm{b}_{\mathrm{ii}} \mathrm{X}_{\mathrm{i}}^{2}+\sum_{\mathrm{i}}^{\mathrm{i}<\mathrm{j}} \sum_{\mathrm{j}} \mathrm{b}_{\mathrm{ij}} \mathrm{X}_{\mathrm{i}} \mathrm{X}_{\mathrm{j}}(i=1,2,3, j=1,2,3)
$$


where $\mathrm{X}_{\mathrm{i}}$ refers to the independent input variable that influences output variable $\mathrm{Y} ; \mathrm{b}_{0}, \mathrm{~b}_{\mathrm{i}}, \mathrm{b}_{\mathrm{ii}}$ and $\mathrm{b}_{\mathrm{ij}}$ are the constant regression coefficients, the $i^{\text {th }}$ linear coefficient, the $i^{\text {th }}$ quadratic coefficient and $i j^{\text {th }}$ interactive coefficient of the equation, respectively.

Uniform Design Software 3.0 (http://www.math.hkbu.edu.hk/Uniform Design/software) was used to evaluate the parameters of the response equations, and corresponding analysis on variations were assessed using MATLAB 7.0. Meanwhile, three-dimensional response surfaces or two-dimensional contour curves were illustrated to give the visual responses of TOC, $\mathrm{NH}_{4}{ }^{+}-\mathrm{N}$ and $\mathrm{PO}_{4}{ }^{3-}-\mathrm{P}$. The confirmation experiments under individual and integrated optimal removal conditions were conducted to testify the accuracy of statistical experimental results.

Optimization for multiple responses. Desirability function approach is the most common method of optimizing multiple responses ${ }^{32,33,36}$. For each system response $Y_{i}$, ideal function $d_{i}\left(Y_{i}\right)$ is assigned the value between the ranges of 0 to 1 . Specifically, $d_{i}\left(Y_{i}\right)=0$ and 1 mean that $Y_{i}$ is a completely undesirable value and a completely desirable response, respectively. Then the general desirable function is obtained by calculating the geometric mean of all individual desirable function together:

$$
D=\left(d_{1}\left(Y_{1}\right) \times d_{2}\left(Y_{2}\right) \times d_{3}\left(Y_{3}\right)\right)^{\frac{1}{3}}
$$

The specific calculation method for the individual desirable function value is as follows:

$$
d_{i}\left(Y_{i}\right)=\left\{\begin{array}{cc}
1 & \text { if } Y_{i}<L_{i} \\
\frac{T_{i}-Y_{i}}{T_{i}-L_{i}} & \text { if } L_{i} \leq Y_{i} \leq T_{i} \\
0 & \text { if } Y_{i}>T_{i}
\end{array}\right.
$$

where $T_{i}$ and $L_{i}$ represent the completely undesirable value and completely desirable value, respectively.

GRA. It is essential to understand the most significant influential parameter for the coagulation process. To prioritize the various factors on the treatment efficiency, grey relational analysis (GRA) ${ }^{37}$ was adopted to identify the interrelationships between multiple factors and variables. The grey relational grade $\gamma$ is obtained by calculating the average values of all the grey relational coefficients with the methods mentioned in previous research ${ }^{38,39}$ as follows:

$$
\gamma\left(z_{0}, z_{j}\right)=\frac{1}{n} \sum_{k=1}^{n} \gamma\left(z_{0}(k), z_{j}(k)\right)(j=1,2, \cdots m)
$$

where $z_{0}$ and $z_{j}$ are the normalized data of the input factors and the output variables, respectively. $\gamma\left(z_{0}(k)\right.$ and $\mathrm{z}_{\mathrm{j}}(\mathrm{k})$ ) are the grey relational coefficient.

The larger grey relational grade $\gamma$ indicates the influential degree of the factor on the system is greater.

\section{References}

1. Chislock, M. F., Doster, E., Zitomer, R. A. \& Wilson, A. Eutrophication: causes, consequences, and controls in aquatic ecosystems. Nat. Educ. Knowl. 4, 10-17 (2013).

2. Renuka, N., Sood, A., Prasanna, R. \& Ahluwalia, A. Phycoremediation of wastewaters: a synergistic approach using microalgae for bioremediation and biomass generation. Int. J. Environ. Sci. Te. 12, 1443-1460 (2015).

3. Wang, X. et al. Probabilistic evaluation of integrating resource recovery into wastewater treatment to improve environmental sustainability. Proc. Natl. Acad. Sci. USA 112, 1630-1635 (2015).

4. Matilainen, A., Vepsäläinen, M. \& Sillanpää, M. Natural organic matter removal by coagulation during drinking water treatment: A review. Adv. Colloid Interface Sci. 159, 189-197 (2010).

5. Shak, K. P. Y. \& Wu, T. Y. Coagulation-flocculation treatment of high-strength agro-industrial wastewater using natural Cassia obtusifolia seed gum: Treatment efficiencies and flocs characterization. Chem. Eng. J. 256, 293-305 (2014).

6. Molina, R., Pariente, I., Rodríguez, I., Martínez, F. \& Melero, J. A. Treatment of an agrochemical wastewater by combined coagulation and Fenton oxidation. J. Chem. Technol. Biot. 89, 1189-1196 (2014).

7. Cao, B. C. et al. The impact of $\mathrm{pH}$ on floc structure characteristic of polyferric chloride in a low DOC and high alkalinity surface water treatment. Water Res. 45, 6181-6188 (2011).

8. Gao, B. Y., Wang, Y., Yue, Q. Y., Wei, J. C. \& Li, Q. The size and coagulation behavior of a novel composite inorganic-organic coagulant. Sep. Purif. Technol. 62, 544-550 (2008).

9. Jiang, J. Q. \& Nigel, J. D. Pre-polymerised inorganic coagulants and phosphorus removal by coagulation-A review. Water SA 24, 237-244 (1998)

10. Nandy, T., Shastry, S., Pathe, P. P. \& Kaul, S. N. Pre-treatment of currency printing ink wastewater through coagulation-flocculation process. Water, Air, and Soil Pollution 148, 15-30 (2003)

11. Hu, C. Z., Liu, H. J., Qu, J. H., Wang, D. S. \& Ru, J. Coagulation Behavior of Aluminum Salts in Eutrophic Water: Significance of Al13 Species and pH Control. Environ. Sci. Technol. 40, 325-331 (2006).

12. Wang, D. S., Tang, H. X. \& Gregory, J. Relative Importance of Charge Neutralization and Precipitation on Coagulation of Kaolin with PACl: Effect of Sulfate Ion. Environ. Sci. Technol. 36, 1815-1820 (2002).

13. Tang, H. X. \& Werner, S. The coagulating behaviors of Fe(III) polymeric species-II. Preformed polymers in various concentrations. Water Res. 21, 123-128 (1987).

14. Tang, H. X. \& Werner, S. The coagulating behaviors of Fe(III) polymeric species-I. Preformed polymers by base addition. Water Res. 21, 115-121 (1987).

15. Teh, C. Y., Wu, T. Y. \& Juan, J. C. Potential use of rice starch in coagulation-flocculation process of agro-industrial wastewater: treatment performance and flocs characterization. Ecol. Eng. 71, 509-519 (2014).

16. Elmaleh, S., Yahi, H. \& Coma, J. Suspended solids abatement by $\mathrm{pH}$ increase-upgrading of an oxidation pond effluent. Water Res. 30, 2357-2362 (1996) 
17. Miller, S. M., Fugate, E. J., Craver, V. O., Smith, J. A. \& Zimmerman, J. B. Toward Understanding the Efficacy and Mechanism of Opuntia spp. as a Natural Coagulant for Potential Application in Water Treatment. Environ. Sci. Technol. 42, 4274-4279 (2008).

18. Syu, M., Chen, B. \& Chou, S. A Study on the Sedimentation Model and Neural Network Online Adaptive Control of a Benzoic Acid Imitated Wastewater Oxidation Process. Ind. Eng. Chem. Res. 42, 6862-6871 (2003).

19. Kan, C. C., Huang, C. P. \& Pan, J. R. Time requirement for rapid-mixing in coagulation. Colloid Surf., A-Physicochem. Eng. Asp. 203, $1-9(2002)$.

20. Yu, W. Z., Gregory, J., Campos, L. \& Li, G. B. The role of mixing conditions on floc growth, breakage and re-growth. Chem. Eng. J. 171, 425-430 (2011)

21. Bezerra, M. A., Santelli, R. E., Oliveira, E. P., Villar, L. S. \& Escaleira, L. A. Response surface methodology (RSM) as a tool for optimization in analytical chemistry. Talanta 76, 965-977 (2008).

22. Khayet, M., Zahrim, A. Y. \& Hilal, N. Modelling and optimization of coagulation of highly concentrated industrial grade leather dye by response surface methodology. Chem. Eng. J. 167, 77-83 (2011).

23. Witek-Krowiak, A., Chojnacka, K., Podstawczyk, D., Dawiec, A. \& Pokomeda, K. Application of response surface methodology and artificial neural network methods in modelling and optimization of biosorption process. Bioresour. Technol. 160, 150-160 (2014).

24. Shak, K. P. Y. \& Wu, T. Y. Optimized use of alum together with unmodified Cassia obtusifolia seed gum as a coagulant aid in treatment of palm oil mill effluent under natural pH of wastewater. Ind. Crop. Prod. 76, 1169-1178 (2015).

25. Fang, K. T., Lin, D. K., Winker, P. \& Zhang, Y. Uniform design: theory and application. Technometrics 42, 237-248 (2000).

26. Fontanier, V., Farines, V., Albet, J., Baig, S. \& Molinier, J. Study of catalyzed ozonation for advanced treatment of pulp and paper mill effluents. Water Res. 40, 303-310 (2006)

27. Jarvie, H. P. et al. Phosphorus mitigation to control river eutrophication: Murky waters, inconvenient truths, and "postnormal" science. J. Environ. Qual. 42, 295-304 (2013).

28. Chen, W., Westerhoff, P., Leenheer, J. A. \& Booksh, K. Fluorescence excitation - Emission matrix regional integration to quantify spectra for dissolved organic matter. Environ. Sci. Technol. 37, 5701-5710 (2003).

29. Li, W. T. et al. Characterization of dissolved organic matter in municipal wastewater using fluorescence PARAFAC analysis and chromatography multi-excitation/emission scan: a comparative study. Environ. Sci. Technol. 48, 2603-2609 (2014).

30. K. Tolkou, A. \& I. Zouboulis, A. Review of Recent Patents on Coagulation/Flocculation (C/F) Process: Methods and Applications with Emphasis on Phosphates Removal. Recent Patents on Materials Science 7, 151-163 (2014).

31. Aguilar, M. I., Sáez, J., Lloréns, M., Soler, A. \& Ortuño, J. F. Nutrient removal and sludge production in the coagulation-flocculation process. Water Res. 36, 2910-2919 (2002).

32. Pinzauti, S. et al. Experimental design in the development of voltammetric method for the assay of omeprazole. J. Pharm. Biomed. Anal. 14, 881-889 (1996).

33. Karande, P., Gauri, S. K. \& Chakraborty, S. Applications of utility concept and desirability function for materials selection. Mater. Des. 45, 349-358 (2013).

34. Ghafari, S., Aziz, H. A., Isa, M. H. \& Zinatizadeh, A. A. Application of response surface methodology (RSM) to optimize coagulation-flocculation treatment of leachate using poly-aluminum chloride (PAC) and alum. J. Hazard. Mater. 163, 650-656 (2009).

35. Trinh, T. K. \& Kang, L. S. Response surface methodological approach to optimize the coagulation-flocculation process in drinking water treatment. Chem. Eng. Res. Des. 89, 1126-1135 (2011).

36. Natrella, M. NIST/SEMATECH e-Handbook of Statistical Methods. (NIST/SEMATECH, 2010).

37. Deng, J. L. Introduction to grey system theory. J. Grey Systems. 1, 1-24 (1989).

38. Haq, A. N., Marimuthu, P. \& Jeyapaul, R. Multi response optimization of machining parameters of drilling $\mathrm{Al} / \mathrm{SiC}$ metal matrix composite using grey relational analysis in the Taguchi method. Int. J. Adv. Manuf. Tech. 37, 250-255 (2008).

39. $\mathrm{Xu}$, J. et al. Evaluating the influence of process parameters on soluble microbial products formation using response surface methodology coupled with grey relational analysis. Water Res. 45, 674-680 (2011).

\section{Acknowledgements}

The authors wish to thank the NSFC (21377123 and 51322802), the Key Special Program on the S\&T for the Pollution Control (2014ZX07204-008), Fok Ying Tong Education Foundation (142024) and the Fundamental Research Funds for the Central Universities for the partial support of this study.

\section{Author Contributions}

N.L. carried out the experiments, analyzed the data, and wrote the paper; G.-P.S. designed the experiments, analyzed the data, and wrote the paper; Y.H. and Y.-Z.L. carried out the experiments, R.J.Z. analyzed the data and wrote the paper.

\section{Additional Information}

Supplementary information accompanies this paper at http://www.nature.com/srep

Competing financial interests: The authors declare no competing financial interests.

How to cite this article: Li, N. et al. Multiple response optimization of the coagulation process for upgrading the quality of effluent from municipal wastewater treatment plant. Sci. Rep. 6, 26115; doi: 10.1038/srep26115 (2016).

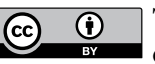

This work is licensed under a Creative Commons Attribution 4.0 International License. The images or other third party material in this article are included in the article's Creative Commons license, unless indicated otherwise in the credit line; if the material is not included under the Creative Commons license, users will need to obtain permission from the license holder to reproduce the material. To view a copy of this license, visit http://creativecommons.org/licenses/by/4.0/ 